\title{
Impact of Cultural Diversity on Western Balkan Countries' Performance
}

\author{
Eglantina Hysa ${ }^{1}$ \\ Department of Economics, Epoka University, Albania
}

\begin{abstract}
In 2005 the relations of EU and Western Balkan countries were passed from "External Relations" to "Enlargement" policy. As WB countries make steps forward in the future membership of the EU, the diversity in society within the WB is expected to further increase. The aim of this paper is to find out the relationship between cultural diversity and ethnic fractionalization from one side and governance, competitiveness and human development from the other side. The paper opted to explore the ethnic diversity within the Western Balkan countries based on the latest data of census for each country and on the Distance Adjusted Ethno-Linguistic Fractionalization Index proposed by Kolo (2012). Furthermore, it compared the economic performance of these countries with the indicators of the ethnic diversity. Even though the literature argues that cultural diversity has negative impact on countries' performance, the study finds out that highly homogenous societies in WB are no more prone to good governance, global competitiveness and human development than highly heterogeneous societies within the region. In other words, countries with lower fractionalization index (such as Kosovo and Serbia) do not show a significantly higher performance than countries with higher fractionalization index (such as Macedonia, Bosnia and Herzegovina). To sum up, the influence of regional geographic distance seems to be much more significant compared to cultural diversity because the economic capacity and performance of WB countries are found to be positive but still modest. The Western Balkan countries are having a considerable mixture of ethnicities, languages and religions. These varieties can push this group of countries to have a consensus among them in the economic aspects or to increase the gap among each other.
\end{abstract}

Keywords: cultural diversity, ethnic fractionalization, governance, global competitiveness, human development, Western Balkans.

\section{Introduction}

From the early stages of the societies, the governments have aimed to reach a harmonization within the population. This harmonization is seen to be emerged in terms of cultural, ethnicity, language, religion and identity. The Western Balkan case is an important case to be investigated, if ethnic, language and religious fractionalization are barriers and impediments to the development of these countries or did these countries succeed to come up with common discussions and thus form some stable democracies (consociationalism). But what does consociationalism mean? Consociationalism can be defined as, "a stable democratic system in deeply divided societies that is based on power sharing between elites

\footnotetext{
${ }^{1}$ Correspondent e-mail: ehysa@epoka.edu.al
} 
from different social groups" (Saurugger, 2013). Other authors such as Hassel (2006) and Lijphart 1999 have highlighted the importance of consociationalism. Bangura (1994), defines consociationalism as "the ideal power sharing". Specifically, he explains it as:

The ideal power sharing arrangement is consociationalism. In this arrangement, ethnic claims of all groups are recognized, but these are presented as interests rather than as non-negotiable principles; ethnic groups are free to bargain with each other in forming a grand alliance to govern the country; élites who represent these groups share out key political offices, and in some cases rotate the leadership of the government itself (Bangura, 1994, p. 37).

There are two main opposite views regarding the ethnicity, language, religion fractionalization. According to some researchers, ethnic diversity is seen as a handicap in the countries' economic performance. Authors such as Mauro (1995), Easterly and Levine (1997) have found that the ethnic diversity and ethnolinguistic factorization are the reason of the poor economic performance of the countries. According to Adler (1986), Culture remains generally invisible and, when visible, we usually think it causes problems. People rarely think that cultural diversity benefits organizations. Montalvo and Reynal-Querol (2002) have analyzed the role that different dimensions of ethnicity play in the process of growth and in particular in the case of African countries. They found that religious conflict (used as a measure of polarization index), is important in explaining negative impact on economic growth, but not the same result is ensured for the ethnolinguistic fragmentation.

On the other hand, there are views that the negative impact of ethnic diversity can be surpassed. One of the ways proposed to facilitate the integration of different communities is the establishment of strong institutions (Easterly, 2001). Tolerance is found to be another important dimension in the acceptance of ethnic diversity (Weldon, 2006). Tolerance is at the same time a characteristic of communities and/or it can be induced by the political perspective of the countries. Social intolerance is often associated with political intolerance in general (Stenner, 2005) which means that the more tolerance is present the more the ethnic diversities are acceptable.

The detailed study of 226 US cities for the time period 1980-2010, Ratna at al. (2017), confirmed a positive impact of diversity in economic benefits. According to the authors, diversity allows for mutually beneficial exchanges across people with different knowledge sets and experiences, even though these exchanges appear to be moderated by linguistic barriers (Ferris, 2019; Parker, 2019; Wilder et al, 2017).

There are studies, such as the one conducted by Kirk et al. (2018), that discussed the issue of "diversity paradox" with "initial increases in diversity leading to unwanted effects and dividends arising as groups mix over generations, which implies a trade-off for countries looking to manage their own diversity or to benefit from global migrations." Thus, here arises the debate of the two sides of the same coin. From one perspective, the diversity (we consider here ethnic, linguistic and religion) can be considered a barrier to the economic growth and development of the countries. Meanwhile, from the other viewpoint, if the governments find out the proper tools and policies to use the diversity as an opportunity, it can serve as a "pushup factor" to the development (Krynski, 2019; Maguth \& Koskey, 2019).

Moreover, the European Union approach seems to embrace cultural diversity as one of the values to the European identity. In the Millennium Declaration adopted at the European Council in Helsinki in December 1999 has been stated that "The Union's citizens are bound together by common values such as freedom, tolerance, equality, solidarity and cultural diversity...", European Union is encouraging policies and practices of tolerance and openness, mainly through normative ("aquis communautaire") and economic instruments, while leaving 
space to national institutional choices and traditions (Hlepas, 2013). Hence, the impact of cultural diversity to the countries' economic performance seems to be an arguable issue (Benlagha \& Hemrit, 2018; Olefirenko \& Galuschenko, 2018).

The paper is structured as follows: The first session is devoted to the literature review which briefly summarizes the indexes used to measure the ethnic diversity. Concurrently it goes over the authors that have proposed and used these indexes and other authors criticizing the related index. The third session explores the ethnic diversity within the Western Balkan countries based on the detailed material of the Central Intelligence Agency in 2008 and on the latest data of census for each country. The fourth session attempts to configure the scores of some important indicators for the economic performance of the countries and to find out somehow the relationship of these indicators with the ethnic diversity. Finally, some conclusions concerning western Balkan countries performance and EU integration are drawn.

\section{Literature Review}

Most of the existing literature on ethnic diversity and economic performance focused on the "fractionalization index" (Alesina \& La Ferrara, 2005). In their study, Easterly and Levine (1997), used as a measure of fragmentation, the probability that two randomly drawn individuals from the unit of observation belong to two different groups. This index varies from 0 to 1, where 1 shows that every individual belongs to a different group.

However, the Ethnic Diversity has been a discussed topic. The table below shows a list of sub-national measurements of ethnic diversity used by different authors.

\section{Table 1}

Sub-National Level Ethnic Diversity

\begin{tabular}{|c|c|}
\hline Index & Authors that have proposed and used \\
\hline Ethnolinguistic & - First brought into economics by Mauro (1995); \\
\hline \multirow[t]{2}{*}{ fragmentation index } & - Dataset of Easterly and Levine (1997). \\
\hline & Criticised by Alesina et al. (2003); Fearon (2003), and Posner (2004). \\
\hline Ethnic & - Proposed by Alesina et al. (2003); \\
\hline \multirow[t]{2}{*}{$\begin{array}{l}\text { fractionalization } \\
\text { index }\end{array}$} & $\begin{array}{l}\text { - Aghion et al. } 2004 \text { found to be robustly correlated with the degree } \\
\text { of insulation of political leader. }\end{array}$ \\
\hline & Criticised by Posner (2004). \\
\hline Linguistic & - Proposed by Alesina et al. (2003); \\
\hline $\begin{array}{l}\text { fractionalization } \\
\text { index }\end{array}$ & $\begin{array}{l}\text { - Used by Alesina et al. (2016) to show that ethnic/linguistic diversity } \\
\text { is uncorrelated with GDP per capita once inequality across ethnic } \\
\text { groups is controlled for. }\end{array}$ \\
\hline \multirow[t]{2}{*}{$\begin{array}{l}\text { Ethnic polarization } \\
\text { index }\end{array}$} & $\begin{array}{l}\text { - Proposed by Montalvo and Reynal-Querol (2005), who apply the } \\
\text { polarization index proposed by Esteban and Ray (1994), and shown } \\
\text { to be correlated with incidence of civil wars; }\end{array}$ \\
\hline & $\begin{array}{l}\text { - Aghion et al. (2004), found to be correlated with the degree of } \\
\text { insulation of political leaders. }\end{array}$ \\
\hline $\begin{array}{l}\text { Linguistic } \\
\text { heterogeneity index }\end{array}$ & $\begin{array}{l}\text { - Desmet et al. (2012) propose a measure of linguistic diversity at } \\
\text { different levels of linguistic aggregation, based on language trees } \\
\text { from the Ethnologue data; }\end{array}$ \\
\hline & $\begin{array}{l}\text { - Used by Alesina et al. (2016) to show that ethnic/linguistic diversity } \\
\text { is uncorrelated with GDP per capita once inequality across ethnic } \\
\text { groups is controlled for; }\end{array}$ \\
\hline & $\begin{array}{l}\text { - Esteban et al. (2012) use the same Ethnologue data to calculate the } \\
\text { distance between two linguistic groups for obtaining a polarization }\end{array}$ \\
\hline
\end{tabular}




\begin{tabular}{|c|c|}
\hline & $\begin{array}{l}\text { index that is more general than the one by Montalvo and Reynal- } \\
\text { Querol (2005) described above (in which the distance between any } \\
\text { two groups is set to be one). }\end{array}$ \\
\hline $\begin{array}{l}\text { Proportion of the } \\
\text { pop. in Africa, } \\
\text { whose ethnic group } \\
\text { lives in also other } \\
\text { countries }\end{array}$ & $\begin{array}{l}\text { - Constructed by Englebert (2000), Treated as the measure of } \\
\text { legitimacy of African states over their population. }\end{array}$ \\
\hline $\begin{array}{l}\text { Ethnopolitical } \\
\text { group indices }\end{array}$ & $\begin{array}{l}\text { - Developed by Scarritt and Mozaffar (1999). "The Specification of } \\
\text { Ethnic Cleavages and Ethnopolitical Groupsfor the Analysis of } \\
\text { Democratic Competition in Contemporary Africa." Nationalism and } \\
\text { Ethnic Politics 5(1); } \\
\text { - Used by Mozaffar et al. (2003) and Blimpo et al. (2013) "Public } \\
\text { Investment in Rural Infrastructure: Some Political Economy } \\
\text { Considerations". }\end{array}$ \\
\hline
\end{tabular}

Source: Devecondata. (2016). Retrieved from http://devecondata.blogspot.al/2007/05/ethnicdiversity.html

As noted in table 1, there are a lot of studies examining the typology of diversity. At the same time, there are other studies trying to analyze the diverse impacts that these divergences might have in different aspects of economy. Again, these studies might be macrolevel studies, micro-level or province-level. Lee et al. (2019) found that in the case of China, ethnic diversity alone worsens economic performance, but indicators of ethnic diversity for education and FDIs have a positive effect on economic performance. Another study on China, a micro-level one, the minimization of ethnic heterogeneity can make firms gain more economic benefits. Some latest studies go further to the analyses of the firms' establishment by the size typology and examine the effect of ethnic diversity on their size. As such, Boudreaux (2020) finds that ethnic diversity positively impacts the small- firm establishments and negatively impacts the largest ones.

\section{Ethnic Diversity in the Western Balkan Countries}

In 2008, the Central Intelligence Agency provided important and detailed information regarding the western Balkan countries' ethnicity. This material consists of the estimated total population of each western Balkan country including the respective ethnicity. Table 2 shows the ethnicity distribution of western Balkan countries. Albania is found to have the lowest ethnic diversification, of about $98 \%$ of the population is Albanian. Kosovo has a relatively low ethnic diversification too; about $89 \%$ of the population is registered as Albanians. Ethnic diversification in Serbia is again not too high, $82 \%$ of the population is found to Serbs. The rest of the western Balkans are very mixed countries. The majority of the population of Macedonia, Bosnia and Herzegovina, and Montenegro are respectively 64\% Macedonian, $52 \%$ Bosniak, and 44\% Montenegrin.

In addition to the above information, Appendix A, Appendix B and Appendix C, show the evolution and the distribution of the ethnicities among the countries of Western Balkan. The maps indicate the distribution for year 2008, 2017 and a comparison of years 1990 and 2015.

The latest data regarding the ethnicity, language and religion are gathered from the official institute of statistics of each country based on the Household Censuses. The last censuses for the western Balkan countries are as follows: Albania in 2011, Bosnia and Herzegovina in 2013, Serbia in 2011, Montenegro in 2003, Macedonia 2002 and Kosovo in 
2011. Since the Censuses of Montenegro and Macedonia provide earlier data than 2008, then they are not being considered in the below description.

\section{Table 2}

Ethnic Distribution in the Western Balkans, 2008

\begin{tabular}{|c|c|}
\hline Country & Ethnic Distribution \\
\hline Albania & 98\% Albanian, $2 \%$ other (including Bulgarian, Greek, \\
\hline Population: 3.190 .000 & Macedonian, Roma and Serb) \\
\hline Bosnia and Herzegovina & $52 \%$ Bosniak, $36 \%$ Serb, $12 \%$ Croat \\
\hline Population: 3.919 .000 & \\
\hline Kosovo & $89 \%$ Albanian, $6 \%$ Serb, $2 \%$ Bosniak, $3 \%$ other (includes Roma) \\
\hline Population: 2.088 .000 & \\
\hline Macedonia & 64\% Macedonian, 26\% Albanian, 2\% Serb, 1\% Bosniak, 7\% \\
\hline Population: 2.064 .000 & other (includes Roma and Turkish) \\
\hline Montenegro & 44\% Montenegrin, $30 \%$ Serb, $13 \%$ Bosniak, $5 \%$ Albanian, $1 \%$ \\
\hline Population: 630.000 & Croat, $7 \%$ other (includes Macedonian and Roma) \\
\hline Serbia & $82 \%$ Serb, $2 \%$ Bosniak, $1 \%$ Croat, $1 \%$ Montenegrin, $1 \%$ \\
\hline Population: 7.283 .000 & Albanian, $13 \%$ other (includes Bulgarian, Hungarian, and Roma) \\
\hline
\end{tabular}

Source: Central Intelligence Agency. (2008). Ethnic distribution in the Western Balkans, Washington, D.C. from https://www.loc.gov/resource/g6841e.ct002411/.

The Population and Housing Census of 2011 is the main data source of ethnicity, language and religion analysis for Albania. According to this dataset ${ }^{2}$, the population ethnicity of the responders is: 97.8\% Albanian and the rest of $2.2 \%$ are Greek, Macedonian, Montenegrin, Aromanian, Roma, Egyptian and others. Albanian language is found to be the mother tongue for $98.9 \%$ of the population. Whereas, there exists a higher religious diversity through population, such as $67.7 \%$ of the responders are Muslims, $12 \%$ Catholics, $8.1 \%$ Orthodox, $2.5 \%$ Bektashi and 9.7\% others (Instat, 2017).

According to Census of population, households and dwellings in Bosnia and Herzegovina, 2013, statistics for ethnic groups in Bosnia and Herzegovina are as follows: $50.11 \%$ Bosniaks, $30.78 \%$ Serbs, $15.43 \%$ Croats, $2.73 \%$ others, $0.71 \%$ not declared and $0.18 \%$ gave no answer. Population percentage by religion in this country is as following: 50.70\% Islam, 30.75\% Orthodox, 15.19\% Catholic, 0.79\% Atheist, $0.31 \%$ Agnostic, $1.15 \%$ other, $0.93 \%$ not declared, $0.19 \%$ no answer. The division of population by mother tongue is: $52.9 \%$ Bosnian, $14.6 \%$ Croatian, $30.7 \%$ Serbian, 1.6 other, 0.2 no answer. (Census, 2013)

Based on the Census 2011, the population of Serbia has the following language distribution: $88.1 \%$ Serbian, 3.4\% Hungarian, 3.3\% Bosnian, and others. Ethnicity division is quite similar to the language one representing $83.3 \%$ Serbs, 3.53\% Hungarians, $2.02 \%$ Bosniaks, 2.05\% Roma people, and others. Lastly, 91.22\% of the Serbian population is Christian (Orthodox, Catholic, Protestant, other Christian), 3.1\% Islam and others. (Census, 2011).

These data corresponding Kosovo are referred to Population and Housing Census 2011. According to this data, this is the ethnic composition of Kosovo: Albanians (92.9\%), Serbs (1.5\%), Bosniaks (1.6\%), Turks (1.1\%), Ashkali (0.9\%), Egyptians (0.6\%), Gorani $(0.6 \%)$, Romani $(0.5 \%)$, others $(0.1 \%)$ and $0.1 \%$ of the population are unspecified. However, it should be mentioned that the results of this Census are considered jeopardized because the north Kosovo was excluded and there was a partial boycott by the Serb and Roma communities.

\footnotetext{
${ }^{2}$ No answered and not relevant questionnaires are excluded from the total percentage of the population.
} 
Apart from national statistical institution of each country, there are some empirical studies offering to the literature some more details on the measurement and different considerations of the diversity in the western Balkan countries. Accordingly, there exist some important studies that have measured and displayed a worldwide database with elements of diversity. Alesina et al. (2003) mostly based their results in information taken from Encyclopedia Britannica and they classify the fractionalization into three categories; ethnic, linguistic and religious. Their study was to test the effects of fractionalization on the quality of institutions and economic growth. Table 3 shows, the extracted data for the countries in western Balkan. The values in bold show the highest values indicating fractionalization. In this context, the language (0.6751) and religious fractionalization rate (0.6851) in Bosnia and Herzegovina are among the highest in the region. However, the third index also, that of ethnicity is still very high (0.6300). Whereas the ethnicity fractionalization (0.8092) was found to be the highest one in Yugoslavia (pre-1991), which is quite understandable. Albania is representing the lowest values for the three indexes, ethnic (0.2204), language (0.0399) and religion (0.4719).

\section{Table 3}

Ethnic, Language and Religion Fractionalization

\begin{tabular}{llll}
\hline Country & Ethnic $^{3}$ & Language $^{4}$ & Religion $^{5}$ \\
\hline Albania & 0.2204 & 0.0399 & 0.4719 \\
Bosnia and Herzegovina & 0.6300 & $\mathbf{0 . 6 7 5 1}$ & $\mathbf{0 . 6 8 5 1}$ \\
Macedonia (Former Yug. Rep) & 0.5023 & 0.5021 & 0.5899 \\
Serbia/Montenegro (Yugoslavia) & 0.5736 &. &. \\
Yugoslavia (pre-1991) & $\mathbf{0 . 8 0 9 2}$ & 0.6060 & 0.5530 \\
\hline Source: Al) & &
\end{tabular}

Source: Alesina, et al. (2003). Fractionalization. Journal of Economic growth, 8(2), 155-194.

The second study offering detailed dataset on the overall countries, is the study of Fearon (2003), which himself defines his methodology of calculating and constructing the ethnic grouping as the "right list" 6 . The cultural diversity measure constructed here used structural relationships between languages as a proxy for cultural similarity, which leaves out other dimensions of cultural resemblance, most notably shared religion (Fearon, 2003). Even in this classification, ethnic fractionalization index is the highest one for Yugoslavia (0.801) and Bosnia and Herzegovina (0.681). Surprisingly, the new index proposed by Fearon (2003), the cultural diversity index is found to be the highest value for Macedonia (0.432) compared to the rest of the region. As per lowest value of indexes, Albania is being the least fractionalized country (ethnic fractionalization index- 0.097, and cultural diversity index0.082). From a list of 159 countries investigated in this study, Albania is in the $147^{\text {th }}$ place, followed by Macedonia in $72^{\text {nd }}$ place, Bosnia in the 41th place and Yugoslavia in the $19^{\text {th }}$ place.

Another Index is proposed by Roeder (2001), who merges the ethnicity and linguistic aspects in one common index, Ethnolinguistic Fractionalization Index (ELF). He has presented the ELF index for two separate years, that of 1961 and 1985. Even though we do not have the full information for the year 1961, it can be emphasized that the indices no

\footnotetext{
${ }^{3}$ Data Sources: Albania, World Directory of Minorities, 1989; other countries, Encyclopedia Brit, 1991 and 1994

${ }^{4}$ Data Sources: Encyclopedia Brit, 2001.

${ }^{5}$ Data Sources: Encyclopedia Brit, 2001.

${ }^{6}$ According to him, the "right list" of ethnic groups "depends on what people in the country identify as the most socially relevant ethnic groupings". This approach has the advantage of being closer to what the theory would want and the disadvantage of having to make judgement calls (or adopt others' judgement calls) about what is the "right list".
} 
severe changes have occurred through time. As the previous data showed, "old" Yugoslavia is the one with the highest ethnolinguistic fractionalization index (0.801 for year 1985), followed by Bosnia (0.701 for year 1985). ELF of Yugoslavia and Macedonia are pretty close to each other, whereas Albania is considered an insignificant fractionalized country.

Table 4

Ethnic and Cultural Diversity, 2003

\begin{tabular}{lll}
\hline Country & Ethnic Fractionalization Index & Cultural Diversity Index $^{7}$ \\
\hline Albania & 0.097 & 0.082 \\
Yugoslavia (1943-1992) & $\mathbf{0 . 8 0 1}$ & 0.385 \\
Macedonia & 0.535 & $\mathbf{0 . 4 3 2}$ \\
Bosnia and Herzegovina & 0.681 & 0.146
\end{tabular}

Source: Fearon, J. D. (2003). Ethnic and cultural diversity by country. Journal of economic growth, 8(2), 195-222.

Table 5

Ethnolinguistic Fractionalization Indices, 1961 and $1985^{8}$

\begin{tabular}{lll} 
& Ethnolinguistic & Ethnolinguistic \\
& Fractionalization (ELF) Indices, & Fractionalization (ELF) Indices, \\
Country & 1961 & 1985 \\
\hline Albania & 0.093 & 0.064 \\
Yugoslavia & n/a & 0.581 \\
Macedonia & n/a & 0.511 \\
Yugoslavia (United) & $\mathbf{0 . 7 5 4}$ & $\mathbf{0 . 8 0 1}$ \\
Bosnia & n/a & 0.701 \\
\hline
\end{tabular}

Source: Philip G. Roeder. (2001). Ethnolinguistic Fractionalization (ELF) Indices, 1961 and 1985.

The latest general study measuring the ethnicity-diversity index is the study of Kolo (2012). This study offers the index for a total of 210 countries, based on an extensive amount of data, containing more than 12,000 groups. The author proposes a new index, the distance adjusted ethno-linguistic fractionalization index (DELF), which is defined using all three characteristics of fractionalization, that of ethnicity, language and religion. The author compares DELF with ELF (ethno-linguistic fractionalization index) and he suggests the new one, DELF, since this index incorporates the fundamental concept of diversity. The author calculates a separate index per each component, labeled with a respective subscript for (L)anguage, $\mathrm{DELF}_{\mathrm{L}},(\mathrm{E})$ thno-culture, $\mathrm{DELF}_{\mathrm{E}}$ and (R)eligion), DELFR. All three components are combined in equal-weighted average to get the general index, DELF.

\footnotetext{
${ }^{7}$ Cultural fractionalization is approximated by a measure of similarity between languages, varying from $1=$ the population speaks two or more unrelated languages to $0=$ the entire population speaks the same language. This index of cultural diversity is biased towards linguistic variations as opposed to genetic diversity and other variations.

${ }^{8}$ ELF Index for years 1961 and 1985 uses none of the groupings reported in the sources when data on subgroups are available. (For example, it treats separate Native American groups as separate ethnic groups rather than combining these in a catch-all "Indigenous Peoples". Similarly, it treats Hutus and Tutsis as separate ethnic groups rather than grouping these as Banyarwanda in Rwanda or Barundi in Burundi). In addition, in settler societies of the Western Hemisphere, this index treats racial distinctions within ethnolinguistic groups (Afro-Americans versus White Americans or Afro-Colombians versus Euro-Colombians) as separate ethnic groups (Roeder, 2001).
} 
Table 6 presents all fractionalization indexes related to Western Balkan countries retrieved from the database of Kolo (2012). Based on this database, ELF value is the highest one for Bosnia and Herzegovina (0.686), however, the highest value for DELF is found to be for Macedonia (0.456). Similarly, to the work of Fearon (2003), who has also used the diversity index ${ }^{9}$, Macedonia is found to be the country with the highest fractionalization in the region. From the three sub-indexes, $D_{E L F}, D_{E L F}$ and $D_{E L F}$, the first two show the highest value for Macedonia, indicating that language and ethno-culture fractionalization are really significant, whereas the religion index is highly fractionalized in Bosnia and Herzegovina.

Table 6

ELF and DELF values ${ }^{10}$

\begin{tabular}{|c|c|c|c|c|c|}
\hline & $\begin{array}{l}\text { Ethno- } \\
\text { Linguistic } \\
\text { Fractionaliz } \\
\text { ation }(\text { ELF })\end{array}$ & $\begin{array}{l}\text { Distance Adj. } \\
\text { Ethno- } \\
\text { Linguistic } \\
\text { Fractionalizatio } \\
\text { n Index (DELF) }\end{array}$ & $\begin{array}{l}\text { DELF values } \\
\text { based on } \\
(L) \text { anguage } \\
\left(D E L F_{L}\right)\end{array}$ & $\begin{array}{l}\text { DELF values } \\
\text { based on } \\
(E) \text { thno-culture } \\
\left(D E L F_{E}\right)\end{array}$ & $\begin{array}{l}\text { DELF } \\
\text { values } \\
\text { based on } \\
(R) \text { eligion } \\
\left(D E L F_{R}\right)\end{array}$ \\
\hline Albania & 0.539 & 0.248 & 0.334 & 0.140 & 0.272 \\
\hline $\begin{array}{l}\text { Bosnia and } \\
\text { Herzegovina }\end{array}$ & 0.686 & 0.351 & 0.273 & 0.281 & 0.499 \\
\hline Kosovo & 0.220 & 0.163 & 0.214 & 0.099 & 0.175 \\
\hline Macedonia & 0.613 & 0.456 & 0.578 & 0.332 & 0.459 \\
\hline Montenegro & 0.671 & 0.223 & 0.219 & 0.167 & 0.283 \\
\hline Serbia & 0.318 & 0.171 & 0.214 & 0.194 & 0.106 \\
\hline
\end{tabular}

Source: Kolo, P. (2012). Measuring a new aspect of ethnicity: The appropriate diversity index (No. 221). Discussion Papers, Ibero America Institute for Economic Research.

As the diversity index proposed by Kolo (2012) considers all the three main components in the fractionalization literature review, and it represents a more convincing methodology, this study will use this index (DELF) to compare and link with the economic outcomes and development of the related countries' conditions.

\section{Ethnic Diversity and Economic Performance of Western Balkan Countries}

It would be important to find out if there is a negative effect of cultural diversity in the countries' performance taking into consideration indicators such as good governance, global competitiveness and human development. By using the comparison method of the abovementioned indicators, this paper tries to perceive whether the hypothesis that cultural diversity negatively affects the countries performance holds.

The worldwide governance indicators $\left(\mathrm{WGI}^{11}\right)$, aggregate indicators of six broad dimensions of governance: Voice and Accountability; Political Stability and Absence of Violence/Terrorism; Government Effectiveness; Regulatory Quality; Rule of Law; Control of Corruption. Each of them is calculated by taking into account other indexed. The detailed

\footnotetext{
9 Both authors, Fearon (2003) and Kolo (2012) have used the diversity index to measure the societies' fractionalization, however the methodology they used in calculating this index is slightly different. In our study we focus on the results of Kolo (2012) given that the data and the methodology used are the latest one.

${ }^{10}$ Kolo (2012) have used the data taken from is the World Christian Encyclopaedia (Barrett et al., 2001).

11 The six aggregate indicators are based on over 30 underlying data sources reporting the perceptions of governance of a large number of survey respondents and expert assessments worldwide
} 
information of the components used to calculate the main indexes is found in Appendix D. Seen as an important element of development and the economic performance of the countries, we consider the inclusion of such an indicator in the comparative analyses of the countries in the region among themselves, and also in the evaluation of economic progress in relation to the ethnical fractionalization. For example, the political stability is considered one of the most important components for the foreign direct investment (FDI). On the other hand, FDIs are found to have a significant impact on the unemployment rate (Vladi \& Hysa, 2019). The study of Hysa et al. (2013) highlight the fact that WB countries suffer from high levels of unemployment, which in a way of the other, this is a consequence of low FDI in this region because of evident political instability. At the same time, the inequality existing in these countries is negatively impacting the growth and development (Hysa, 2014).

As per Figure 1, Montenegro shows the best performance in the region, even though this is not a remarkable performance. The six dimensions of this indicator are ranged from 2.5 (bad) to +2.5 (good). The values of this indicator rarely are found to be positive for the whole region, and thus, the peak of this value is found in 2012 for Montenegro (0.15). Although Serbia and Albania show some positive values in the last years, the good governance indicator are below zero in the Western Balkan region. This means that governance performance is below the average. Kosovo, Bosnia and Herzegovina, and Albania show a low performance through the years. The outcomes of this index are consistent with the literature on the western Balkan countries. Hysa (2011) in her study, examines the relationship between corruption and human development, western Balkan countries are found to have high corruption levels, which at the same time are strongly related to low performance of human development index.

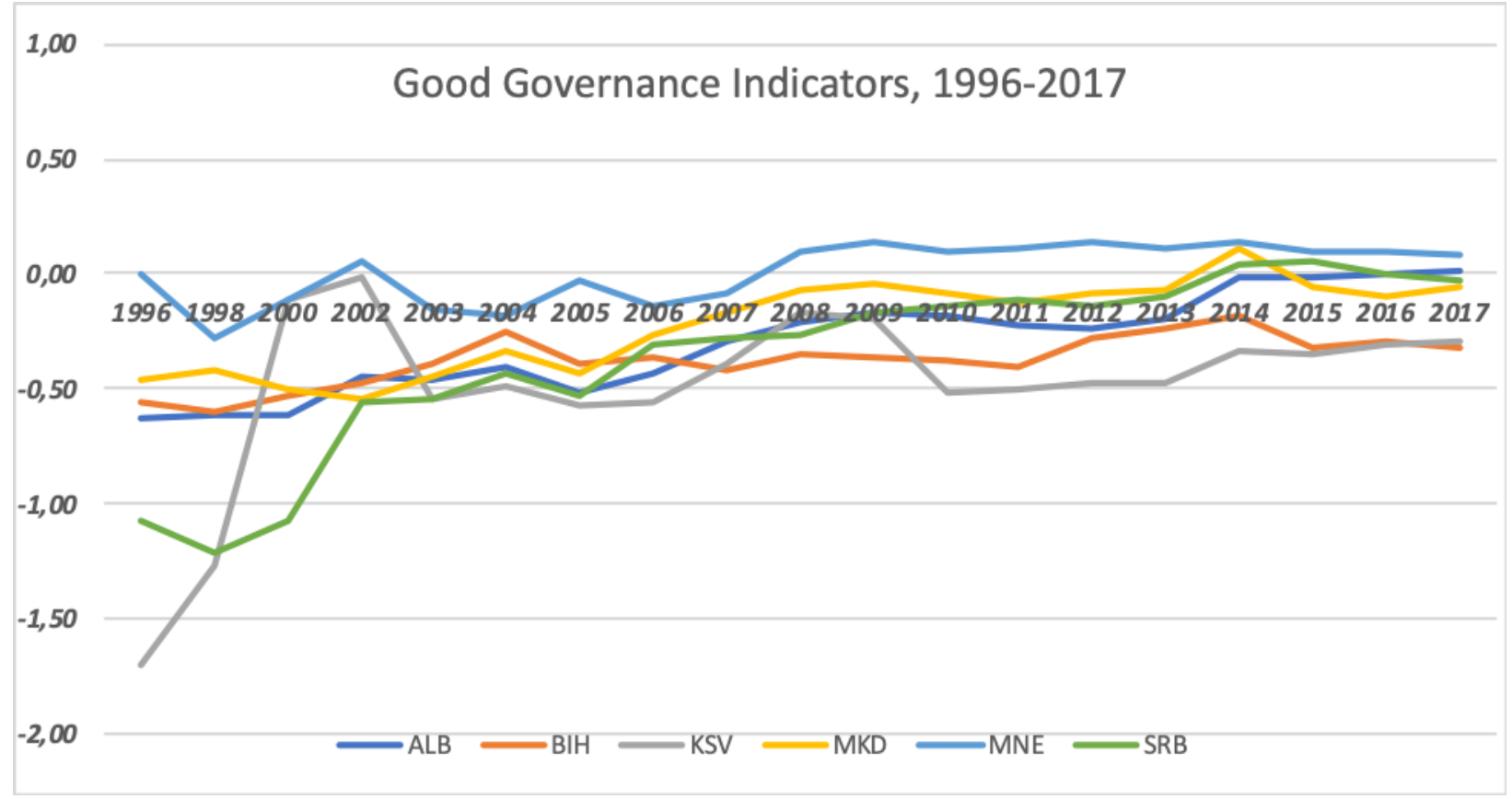

Figure 1. Good Governance Indicators, 1996-2017 ${ }^{12}$

\footnotetext{
${ }^{12}$ Worldwide Governance Indicators (WGI) cover over 200 countries and territories, measuring six dimensions of governance starting in 1996: Voice and Accountability, Political Stability and Absence of Violence/Terrorism, Government Effectiveness, Regulatory Quality, Rule of Law, and Control of Corruption. The aggregate indicators are based on several hundred individual underlying variables, taken from a wide variety of existing data sources. The data reflect the views on governance of survey respondents and public, private, and NGO sector experts worldwide. The WGI also explicitly report margins of error accompanying each country estimate.
} 
Source: The Worldwide Governance Indicators. (2018). Updated version, retrieved from www.govindicators.org

Compared with the EU countries, the negative association of these two indicators are found to be much more robust in some countries of WB (Hysa, 2011). These high levels of corruption, for instance, in Albania, are continuing to be so because of the existing problems with the rule of law (Pici et al., 2014). Therefore, all the good governance indicators are tightly related to each other, hence, an improvement of one of the indicators positively affects the others, and vice-versa.

The Global Competitiveness Index (GCI) captures the determinants of long-term growth. The Index Scale ranges from 1 to 7. The Western Balkan countries are very near to each other taking into account the GCI scores. Macedonia shows the best trend compared to other countries in the region. The highest score in global competitiveness index equal to 4.23 (for year 2016-2017), whereas Bosnia and Herzegovina has the lowest one of 3.89 (for year 2017-2018). Albania, Bosnia and Herzegovina, and Serbia have done some further steps in the last years, while Macedonia and Montenegro have shown some ups and downs in the general trend.

Table 7

The Global Competitiveness Index, Western Balkan Countries

\begin{tabular}{llllll}
\hline \multicolumn{7}{l}{ The Global Competitiveness Index } \\
Countries & $2013-2014$ & $2014-2015$ & $2015-2016$ & $2016-2017$ & $2017-2018$ \\
\hline Albania & 3.85 & 3.84 & 3.93 & 4.06 & 4.18 \\
Bosnia and & & & & & \\
Herzegovina & 4.02 & $\mathrm{n} / \mathrm{a}$ & 3.71 & 3.80 & 3.89 \\
Kosovo $^{13}$ & $\mathrm{n} / \mathrm{a}$ & $\mathrm{n} / \mathrm{a}$ & $\mathrm{n} / \mathrm{a}$ & $\mathrm{n} / \mathrm{a}$ & $\mathrm{n} / \mathrm{a}$ \\
Macedonia & 4.14 & 4.26 & 4.28 & 4.23 & $\mathrm{n} / \mathrm{a}$ \\
Montenegro & 4.20 & 4.23 & 4.20 & 4.05 & 4.16 \\
Serbia & 3.77 & 3.90 & 3.89 & 3.97 & 4.14
\end{tabular}

Sources: World Economic Forum, The Global Competitiveness Report 2013-2014, 20142015, 2015-2016, 2016-2017, 2017-2018.

The last index used to measure the countries' performance is the Human Development Index (HDI). According to HDI, there are four categories of ranking, such as: very high human development, high human development, medium human development and low human development. This index is ranged from 0 (bad) to 1 (good). For year 2018, Montenegro is the country having the highest HDI score of about 0.814 . This country is ranked in the very high development countries list, being in the $50^{\text {th }}$ place. The rest of the countries are very near to each other. All these countries are found in the second category of ranking, that of high human development. Serbia holds the $67^{\text {th }}$ place, Albania the $68^{\text {th }}$ place, Bosnia and Herzegovina the $77^{\text {th }}$ place and Macedonia the $80^{\text {th }}$ one. Again, there are no available data for Kosovo. However, Hoxhaj et al. (2014) mentioned that the HDI for Kosovo has slightly increased due to the improvement of the education attainment in this country.

\footnotetext{
These reflect the inherent difficulties in measuring governance using any kind of data. Even after taking these margins of error into account, the WGI permit meaningful cross-country and over-time comparisons (Kaufmann et al., 2010).

${ }^{13}$ Kosovo has not been considered at any of the reports.

${ }^{14}$ Macedonia was excluded from the report because of insufficient data of year 2017-2018.
} 
Based on Figure 2, all the Western Balkan Countries are showing an increasing trend of human development index (even though this positive trend is roughly slow). The trends confirm Montenegro as the best in the region (throughout all the years), and both Bosnia and Herzegovina and the former Yugoslav Republic of Macedonia are among the countries showing low performance.

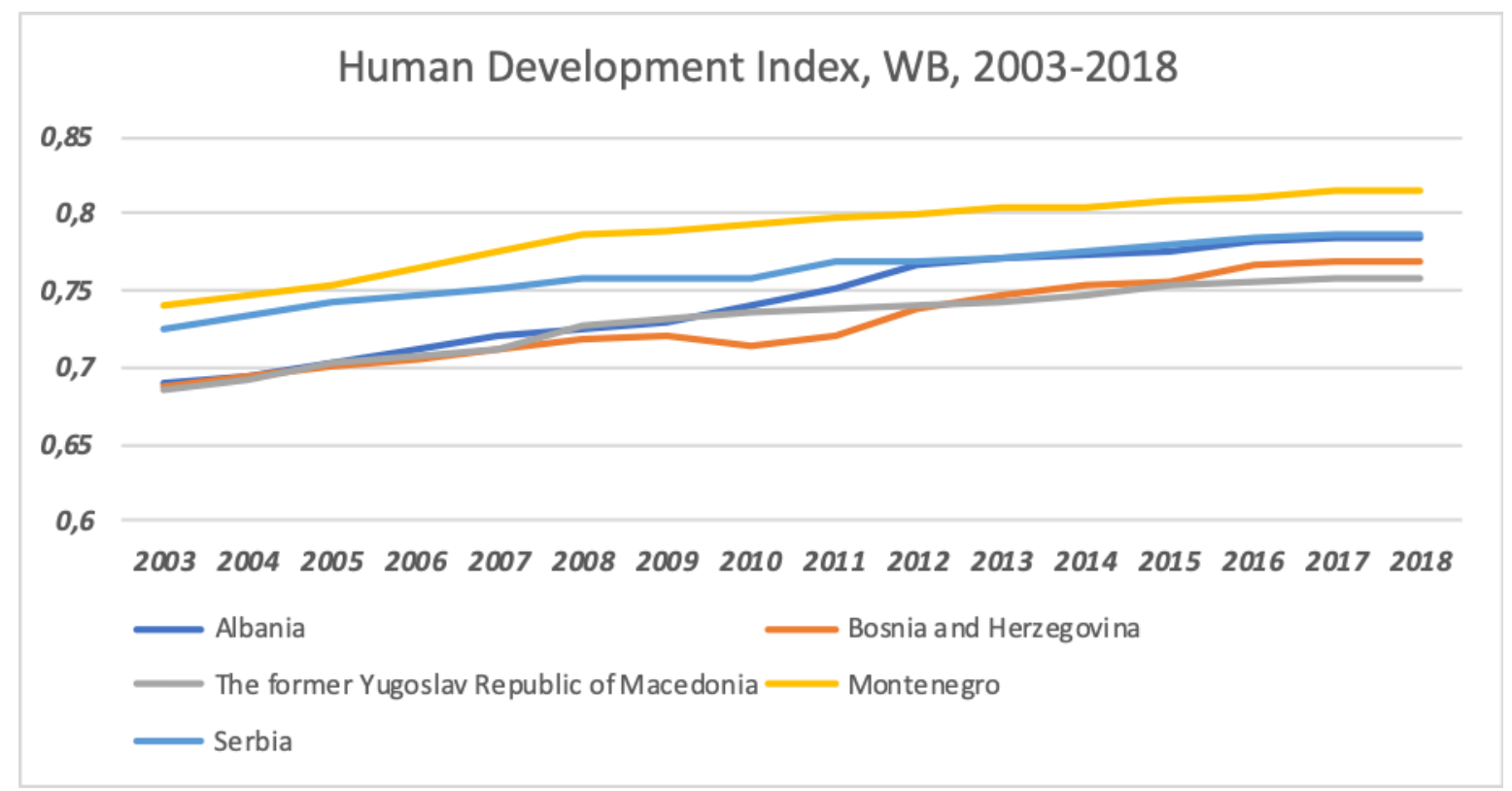

Figure 2. Human Development Index Trend, Western Balkan Countries

In order to measure the cultural diversity and to simplify the comparison, the study takes into account just the Distance Adjusted Ethno-Linguistic Fractionalization Index $(D E L F)$ because this index includes all three important components that for the diversity: language, ethno-culture, and religion). Distance Adjusted Ethno-Linguistic Fractionalization Index has been retrieved from the study of Kolo (2012). This index ranges from 0 to 1; 0 means an absolute language, ethno-linguistic and religious homogeneity and 1 means a complete heterogeneity. Kosovo (DELF value of 0.163) and Serbia (DELF value of 0.171) represent the countries less heterogeneous in the region. The population heterogeneity is found to be relatively high for Macedonia (DELF value of 0.456) and Bosnia and Herzegovina (DELF value of 0.351 ).

Table 8 included the three selected variables explaining to some extent the countries; development and economic performance, good governance indicator, global competitive index and human development index. As stated from other studies, the three economic indicators are strongly related to each other, for example Hysa and Çela (2019) conclude that there is a bi-direction relation among good governance and human development. Good governance indicators such as government effectiveness and voice and accountability depend on human development (Beckett \& Kobayashi, 2020; Feruni \& Hysa, 2020; Nguyen et al., 2018). This study compares these economic indicators with the Distance Adjusted EthnoLinguistic Fractionalization Index, to show if there exists an inverse relationship among them. The figures in bold show the country having the worst value in the region, whereas the underlined figures show the best value (the country with the best economic performance or the least fractionalized country).

According to data given in table 8, Kosovo is expected to have the best economic performance. Contradictory, we find Kosovo ranked the second at the bottom of the group of western Balkan countries regarding good governance. The two other indicators of economic 
performance are missing for this country. Serbia is the second country in the region being less heterogeneous. Even though this country is having the worst global competitive index in the region, this country is showing a relatively good performance regarding two other economic indicators.

Surprisingly, Macedonia having the highest fractionalization index $(0.456)$, has the best global competitive index in the region. Meanwhile, human development index is the lowest in the region and governance indicator is not so bad. Thus. The case of Macedonia is showing some contradictory results.

Table 8

Comparison of Indicators, Western Balkan Countries

\begin{tabular}{|c|c|c|c|c|}
\hline Countries & $\begin{array}{l}\text { Distance Adj. } \\
\text { Ethno-Linguistic } \\
\text { Fractionalization } \\
\text { Index }(\text { DELF })^{15}\end{array}$ & $\begin{array}{l}\text { Good } \\
\text { Governance } \\
\text { Indicator }^{16}\end{array}$ & $\begin{array}{l}\text { Global } \\
\text { Competitive } \\
\text { Index }{ }^{17}\end{array}$ & $\begin{array}{l}\text { Human } \\
\text { Development } \\
\text { Index }\end{array}$ \\
\hline Albania & 0.248 & 0.01 & 4.18 & 0.785 \\
\hline $\begin{array}{l}\text { Bosnia and } \\
\text { Herzegovina }\end{array}$ & 0.351 & -0.32 & 3.89 & 0.768 \\
\hline Kosovo & $\underline{0.163}$ & -0.30 & $\mathrm{n} / \mathrm{a}$ & $\mathrm{n} / \mathrm{a}$ \\
\hline Macedonia & 0.456 & -0.05 & $\underline{4.23^{19}}$ & 0.757 \\
\hline Montenegro & 0.223 & $\underline{0.09}$ & 4.16 & $\underline{0.814}$ \\
\hline Serbia & 0.171 & -0.02 & 4.14 & 0.787 \\
\hline
\end{tabular}

Bosnia and Herzegovina, the second country with the highest fractionalization index (0.351), is having the worst values for both, governance and global competitiveness. Human development index is relatively low compared to the rest of the countries. This result is based on the macro-level study we applied in this research. However, some micro-level studies, such as that of Efendic and Pugh (2017), state that for the case of Bosnia and Herzegovina, the personal and family incomes are $10 \%$ higher in ethnically diverse than in ethnically homogenous areas.

Lastly, Albania and Montenegro, being somehow homogenous countries, are showing satisfied results in the three indices of the economic performance.

Summing up all the results of the indicators measuring the countries performance and comparing these results with the "Ethno-Linguistic Fractionalization" or otherwise defined as the "Cultural Diversity", it is hard to come up to a conclusion regarding the direction of correlation (positive, negative or no relation at all). For the western Balkan case the cultural diversity it is not seen as an ambiguity for the countries' performance

15 Data Sources: Kolo, P. (2012). Measuring a new aspect of ethnicity: The appropriate diversity index (No. 221). Discussion Papers, Ibero America Institute for Economic Research. This data is related to year 2016-2017 because of no available data for the forthcoming year.

16 Data Sources: The Worldwide Governance Indicators. (2018). Updated version, retrieved from www.govindicators.org

${ }^{17}$ Data Sources: World Economic Forum. (2016). The Global Competitiveness Report 2016-2017, Retrieved from http://www3.weforum.org/docs/GCR20162017/05FullReport/TheGlobalCompetitivenessReport2016-2017_FINAL.pdf.

World Economic Forum. (2017). The Global Competitiveness Report 2017-2018, Retrieved from http://www3.weforum.org/docs/GCR20172018/05FullReport/TheGlobalCompetitivenessReport2017\%E2\%80\%932018.pdf

${ }^{18}$ Data Sources: United Nations Development Program. (2018). Human Development Report, Retrieved from http://hdr.undp.org/en/composite/HDI. 


\section{Conclusion}

While examining the correlation of ethnic diversity and economic performance and countries' development, it is highly recommended the consideration of long-run period. The changes of ethnic societies happen during a long period of time and therefore, their impact and outcomes in the countries' economic conditions can be obvious over a long-run period. In the literature discussions about the ethnic diversity define it as population fractionalization, which might be considered as cultural diversity, language diversity, religious diversity or any possible combination of these subcategories. Even though there are some studies offering data on cultural diversity, generally these data are limited. The latest data we could find on the cultural diversity, specifically the Distance Adjusted Ethno-Linguistic Fractionalization Index, was that of Kolo (2012).

At the same time, the measurement of economic performance is largely being discussed. In this study, we have considered three main indexes that capture three different aspects of the economic performance of one country. Accordingly, good governance indicator shows the general environment reflecting accountability, political stability, corruption level, rules of law, quality, etc. The second index used to conceptualize the economic performance of a country is the global competitive index. This index integrates both the macro and micro aspects of competitiveness into a single index. The third selected variable to understand the economic performance of the countries is the human development index, which includes education, health and income indices. Being different from each other, but at the same time complementary to each other, these indexes are important insights for the economic performance.

For the first time, we have a study focusing on the correlation of ethnic diversity and economic performance for the Western Balkan region, making this study novel in itself. Additionally, we consider the macro-level analyse of this region. Western Balkan countries have a quite similar economic performance with each other. In the group of western Balkan countries, Bosnia and Herzegovina shows the weakest economic performance but at the same time, this country is having the second highest diversity fractionalization index in the region. From the other side, Serbia has the second lowest diversity index, and surprisingly, the economic indicators are good enough comparing to the region. This means that for this case the indirect relationship of cultural diversity and economic performance does not hold. These results are consistent with the existing literature, showing different results for different countries and regions. To sum up, even though Western Balkans is a mixed region, there does not exist a clear link between cultural diversity and economic performance.

\section{References}

Adler, N. J. (1986). International dimensions of organizational behavior. Thunderbird International Business Review, 28(1), 31-32. https://doi.org/10.1002/tie.5060280112

Agency for Statistics of Bosnia and Herzegovina. (2016). Census of population, households and dwellings in Bosnia and Herzegovina, 2013: Final results. http://www.popis2013.ba/popis2013/doc/Popis2013prvolzdanje.pdf.

Aghion, P., Alesina, A., \& Trebbi, F. (2004). Endogenous political institutions. The Quarterly Journal of Economics, 119(2), 565-611. https://doi.org/10.1162/0033553041382148

Alesina, A., \& Ferrara, E. L. (2005). Ethnic diversity and economic performance. Journal of economic literature, 43(3), 762-800. https://doi.org/10.1257/002205105774431243

Alesina, A., Devleeschauwer, A., Easterly, W., Kurlat, S., \& Wacziarg, R. (2003). Fractionalization. Journal of Economic growth, 8(2), 155-194. https://doi.org/10.2139/ssrn.319762 
Alesina, A., Michalopoulos, S., \& Papaioannou, E. (2016). Ethnic inequality. Journal of Political Economy, 124(2), 428-488. https://doi.org/10.1086/685300

Bangura, Y. (1994). The search for identity: Ethnicity, religion and political violence (Occasional Paper, No. 6). UNRISD: World Summit for Social Development.

Barrett, D. B., Kurian, G. T., \& Johnson, T. M. (2001). World Christian Encyclopedia; A Comparative Survey of Churches and Religions in the Modern World ( $2^{\text {nd }}$ ed.). United Kingdom: Oxford University Press.

Beckett, G. H., \& Kobayashi, M. (2020). A Meta-study of an Ethnographic Research in a Multicultural and Multilingual Community: Negotiations, Resources, and Dilemmas. American Journal of Qualitative Research, 4(1), 85106. https://doi.org/10.29333/ajqr/8267

Benlagha, N., \& Hemrit, W. (2018). The inter and intra Relationship between Economics, Administrative sciences and Social sciences disciplines. Research in Social Sciences and Technology, 3(3), 92-115. https://doi.org/10.46303/ressat.03.03.6

Blimpo, M. P., Harding, R., \& Wantchekon, L. (2013). Public investment in rural infrastructure: Some political economy considerations. Journal of African Economies, 22, 57-83. https://doi.org/10.1093/jae/ejt015

Boudreaux, C. J. (2020). Ethnic diversity and small business venturing. Small Business Economics, 54(1), 25-41.

Central Intelligence Agency. (2008). Ethnic distribution in the Western Balkans, 2008. https://www.loc.gov/resource/g6841e.ct002411/

Central Intelligence Agency. (2019). Cartography Center in United States. https://www.loc.gov/

Churchill, S. A., Valenzuela, M. R., \& Sablah, W. (2017). Ethnic diversity and firm performance: Evidence from China's materials and industrial sectors. Empirical Economics, 53(4), 1711-1731.

Desmet, K., Ortuño-Ortín, I., \& Wacziarg, R. (2012). The political economy of linguistic $\begin{array}{lll}\text { cleavages. Journal of development } & \text { Economics, 97(2), 322-338. }\end{array}$ https://doi.org/10.1016/j.jdeveco.2011.02.003

Devecondata. (2016, April 22). Ethnic diversity. http://devecondata.blogspot.al/2007/05/ethnic-diversity.html

Easterly, W. (2001). Can institutions resolve ethnic conflict? Economic Development \& Cultural Change, 49(4), 687-706. https://doi.org/10.2139/ssrn.248579

Easterly, W., \& Levine, R. (1997). Africa's growth tragedy: Policies and ethnic divisions. The Quarterly Journal of Economics, 112(4), 1203-1250. https://doi.org/10.1162/003355300555466

Economist Intelligence Unit. (2015). Economic and geopolitical insight guiding the world's organizations. Retrieved from, www.eiu.com

Efendic, A., \& Pugh, G. (2017). Ethnic diversity and economic performance-An empirical investigation using survey data (Economics Discussion Papers, No 2017-57). Kiel Institute for the World Economy.

Englebert, P. (2000). Pre-colonial institutions, post-colonial states, and economic development in tropical Africa. Political Research Quarterly, 53(1), 7-36. https://doi.org/ 10.2307/449244

Esteban, J. M., \& Ray, D. (1994). On the measurement of polarization. Econometrica: Journal of the Econometric Society, 819-851. https://doi.org/10.2307/2951734

Esteban, J., Mayoral, L., \& Ray, D. (2012). Ethnicity and conflict: An empirical study. American Economic Review, 102(4), 1310-1342. https://doi.org/10.1257/aer.102.4.1310

Fearon, J. D. (2003). Ethnic and cultural diversity by country. Journal of Economic Growth, 8(2), 195-222. https://doi.org/10.1023/A:1024419522867 
Ferris, E. (2019). Lessons of Policing and Exclusion. Journal of Culture and Values in Education, 2(3), 25-43. https://doi.org/10.46303/jcve.03.02.2

Feruni, N., \& Hysa, E. (2020). Free Trade and Gravity Model: Albania as Part of Central European Free Trade Agreement (CEFTA). In Theoretical and Applied Mathematics in International Business (pp. 60-90). IGI Global.

Hassel, A. (2006). Wage setting, social pacts and the euro. A new role for the state. Amsterdam University Press.

Hlepas, N. (2013). Cultural diversity and national performance. http://www. ub. edu/sea rchproject/wp-content/uploads/2013/01/WP-5.6. pdf

Hoxhaj, J., Bllaci, D., Hodo, M., Pici, E., \& Hysa, E. (2014). Millennium development goals, MDG'S; Case of Kosovo. Mediterranean Journal of Social Sciences, 5(14), 123-123. https://doi.org/10.5901/mjss.2014.v5n14p123

Hysa, E. (2011). Corruption and human development correlation in Western Balkan countries. EuroEconomica, 4(30), 148-157.

Hysa, E. (2011). Corruption and human development: Albania and EU-27. Social Studies Journal, 5(2), 43-52.

Hysa, E. (2014). Inequality and Human Development. In Proceedings in GV-Global Virtual Conference (No. 1)

Hysa, E., \& Çela, A. (2019). Relationship between Governance and Human Development in European Countries: Panel Regression Analysis. IAI Academic Conference, Rome, 60-71.

Hysa, E., Gjurra, A., \& Binaj, E. (2013). Comparative economic development: AlbaniaWestern Balkan. EuroEconomica, 32(1), 1-14.

Instat (Institute of Statistics of Albania). (2017). http://www.instat.gov.al/al/census.aspx.

Kaufmann, D., Kraay, A., \& Mastruzzi, M. (2010). The worldwide governance indicators: A summary of methodology, data and analytical issues (Working Paper, No. 5430). World Bank Policy Research.

Kirk, T., Stein, D., \& Fisher, A., (2018). The relationship between ethnic diversity \& development: A diversity dividend? Konung International. https://assets.publishing.service.gov.uk/media/5b507c88e5274a73380f7b3e/The_Relat ionship_between_Ethnic_Diversity__Development-

_A_Diversity_Dividend_Kirk__Stein__Fisher_21.6.18.pdf

Kolo, P. (2012). Measuring a new aspect of ethnicity: The appropriate diversity index (Discussion papers, No. 221). Ibero America Institute for Economic Research.

Kosovo Agency of Statistics. (2012). Final results of 2011 census. Retrieved from https://ask.rks-gov.net/media/3282/report-census-in-kosovo-2011.pdf

Krynski, A. (2019). In a State of Fragility: The Compromised Dignity of Communities, Indignation, and the Incapacitation of Public Education. Journal of Culture and Values in Education, 2(3), 1-24. https://doi.org/10.46303/jcve.03.02.1

Lee, S. Y., Lim, E. J., \& Meng, Q. (2019). Ethnic diversity and economic performance in China: The role of education, FDI, and Trade. Emerging Markets Finance and Trade, 55(2), 337-350. https://doi.org/10.1080/1540496X.2018.1429906

Library of Congress. (2017). Copyright Stratfor. https://www.stratfor.com/sites/default/files/styles/strat for_large_s_/public/main/images/western_balkan_ethnicities2.png?itok=JBM99tEG.

Lijphart, A. (1999). Patterns of democracy. Government forms and performance in thirty-six countries. New Haven, CT: Yale University Press.

Maguth, B , Koskey, K . (2019). Preparing Urban Youth to Live-up to their Civic Promise? Researching Youth Positionality of Civic Engagement Using an Arts-Based 
Instrument. Journal of Social Studies Education Research, 10 (1), 1-37. Retrieved from https://jsser.org/index.php/jsser/article/view/397/350

Mauro, P. (1995). Corruption and growth. The Quarterly Journal of Economics, 110(3), 681712. https://doi.org/10.2307/2946696

Montalvo, J. G., \& Reynal-Querol, M. (2002). The effect of ethnic and religious conflict on growth. Retrieved from http://www.econ.upf.edu/ montalvo/wp/rel_ethn.pdf

Montalvo, J. G., \& Reynal-Querol, M. (2005). Ethnic polarization, potential conflict, and civil wars. The American Economic Review, 95(3), 796-816. https://doi.org/10.1257/0002828054201468

Mozaffar, S., Scarritt, J. R., \& Galaich, G. (2003). Electoral institutions, ethnopolitical cleavages, and party systems in Africa's emerging democracies. American Political Science Review, 97(3), 379-390.

Nguyen, P., Corona, R., DeCarlo, M. P., Yaros, A., Le, A. T., \& Compton, K. (2018). Help Seeking Behavior in a Diverse Sample of Asian American Adults. Journal of Ethnic and Cultural Studies, 5(2), 1-15.

Olefirenko, A., \& Galuschenko, A. (2018). Major Features, Benefits, and Prerequisites for Intelligent Enterprise Managing System. Research in Social Sciences and Technology, 3(3), 68-91. https://doi.org/10.46303/ressat.03.03.5

Parker, J. (2019). Second language learning and cultural identity. Journal Of Curriculum Studies Research, 1(1), 33-42. https://doi.org/10.46303/jcsr.01.01.3

Pici, E., Pasmaciu, J., Hysa, E., Hoxhaj, J., \& Hodo, M. (2014). Evaluation of millennium development goals process: Case of Albania. Mediterranean Journal of Social Sciences, 5(14), 33-40. https://doi.org/10.5901/mjss.2014.v5n14p33

Posner, D. N. (2004). The political salience of cultural difference: Why Chewas and Tumbukas are allies in Zambia and adversaries in Malawi. American Political Science Review, 98(4), 529-545. https://doi.org/10.1017/S0003055404041334

Ratna, N., Grafton, R., \& To, H. (2017). The 'paradox of diversity': Economic evidence from US cities 1980-2010. Asia \& the Pacific Policy Studies, 4(1), 20-37. https://doi.org/10.1002/app5.162

Reddit Inc. (2019). Western Balkans predominant ethnic groups in 1990 and 2015, 2018. https://www.reddit.com/r/europe/comments/8ycrsa/western_balkans_predominant_eth nic_groups_in_1990/

Roeder, P. G. (2001). Ethnolinguistic fractionalization (ELF) indices, 1961 and 1985. Retrieved from http//:weber.ucsd.edul proederlelf.htm

Saurugger, S. (2013). Consociationalism. Retrieved from https://www.britannica.com/topic/consociationalism

Scarritt, J. R., \& Mozaffar, S. (1999). The specification of ethnic cleavages and ethnopolitical groups for the analysis of democratic competition in contemporary Africa. Nationalism and Ethnic Politics, 5(1), 82-117. https://doi.org/10.1080/13537119908428555

Statistical Office of the Republic of Serbia. (2011). Census of population, households and dwellings in the Republic of Serbia. Religion, mother tongue and ethnicity: Data by municipalities and

cities. http://pod2.stat.gov.rs/ObjavljenePublikacije/Popis2011/Knjiga4_Veroispovest.pdf

Stenner, K. (2005). The authoritarian dynamic. United Kingdon: Cambridge University Press. https://doi.org/10.1017/CBO9780511614712

The Worldwide Governance Indicators. (2018). Updated version. Retrieved from www.govindicators.org

United Nations Development Program. (2018). Human development report. Retrieved from http://hdr.undp.org/en/composite/HDI 
Vladi, E., \& Hysa, E. (2019). The impact of macroeconomic indicators on unemployment rate: Western Balkan countries. In H. Chandan, \& B. Christiansen (Eds.), international firms' economic nationalism and trade policies in the globalization era (pp. 158-181). IGI Global. https://doi.org/10.4018/978-1-5225-7561-0.ch009

Weldon, S. A. (2006). The institutional context of tolerance for ethnic minorities: A comparative, multilevel analysis of Western Europe. American Journal of Political Science, 50(2), 331-349. https://doi.org/10.1111/j.1540-5907.2006.00187.x

Wilder, L. K., Sanon, D., Carter, C., \& Lancellot, M. (2017). Narrative Ethnographies of Diverse Faculty in Higher Education:" Moral" Multiculturalism among Competing Worldviews. Journal of Ethnic and Cultural Studies, 4(2), 1-12.

World Economic Forum. (2016). The global competitiveness report 2016-2017. http://www3.weforum.org/docs/GCR20162017/05FullReport/TheGlobalCompetitivenessReport2016-2017_FINAL.pdf.

World Economic Forum. (2017). The global competitiveness report 2017-2018. http://www3.weforum.org/docs/GCR2017-

2018/05FullReport/TheGlobalCompetitivenessReport2017\%E2\%80\%932018.pdf

\section{Notes on Contributors}

Associate Professor, Dr. Eglantina Hysa, is a Lecturer of Economics at the Epoka University where she teaches International Economy, Development and Growth, and Microeconomics courses. Her research is concentrated on the fields of development economics, social aspects and quality in higher education institutions. Academic Profile: ORCID: https://orcid.org/0000-0002-3429-5738, Scopus ID: 56005581900, Researcher ID: T7876-2018. 
Hysa, E

\section{Appendices}

Appendix A

Ethnic Distribution in the Western Balkans, 2008

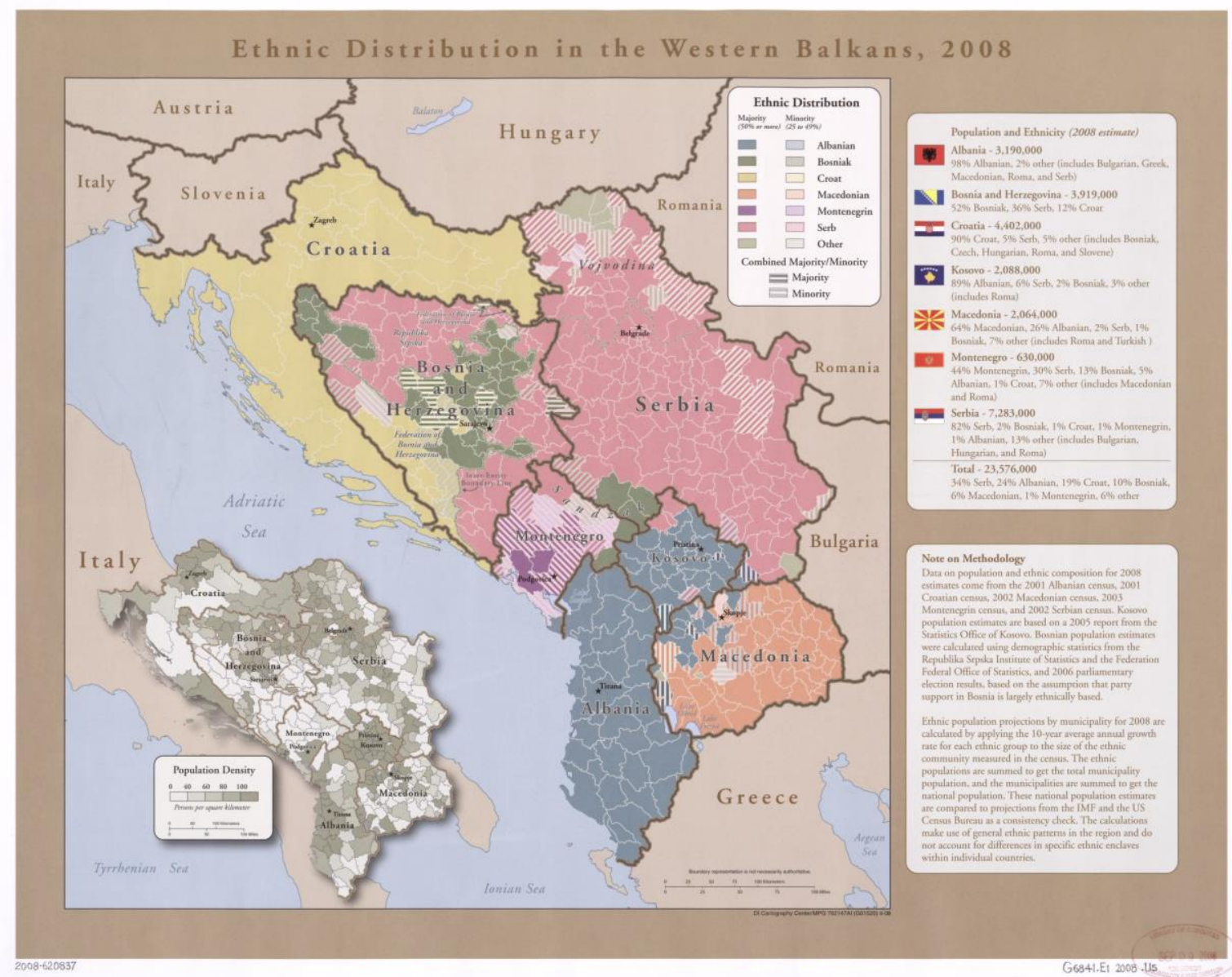

Source: Central Intelligence Agency (2019). Cartography Center in United States. https://www.loc.gov/. 
Appendix B

Ethnic Distribution in the Western Balkans, 2017

\section{Ethnic Distribution in the Western Balkans}

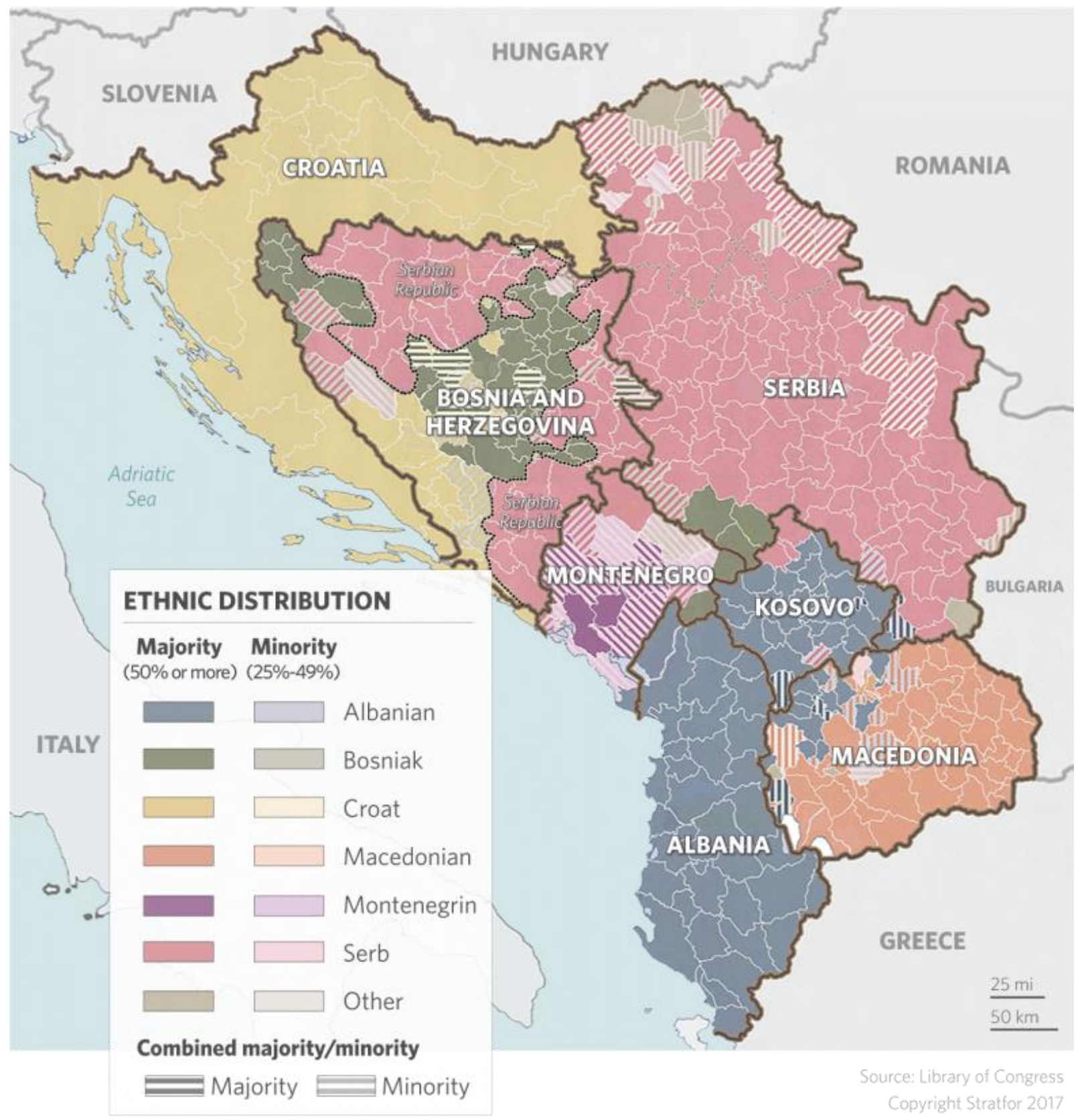

Source: Library of Congress (2017), Copyright Stratfor. https://www.stratfor.com/sites/default/files/styles/stratfor_large_s_/public/main/images/west ern_balkan_ethnicities-2.png?itok=JBM99tEG 
Appendix C

Western Balkans Predominant Ethnic Groups in 1990 and 2015
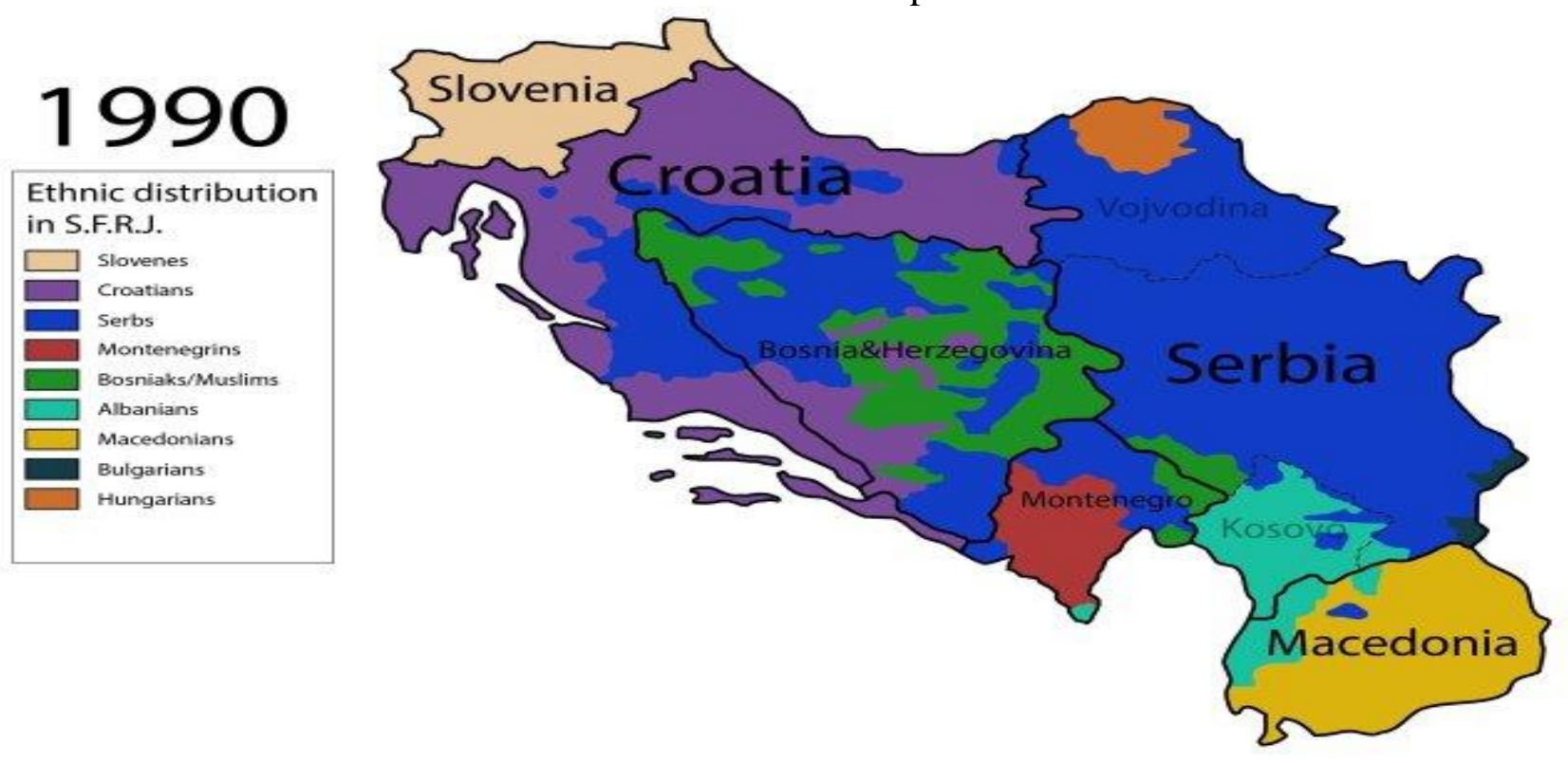

\section{5}
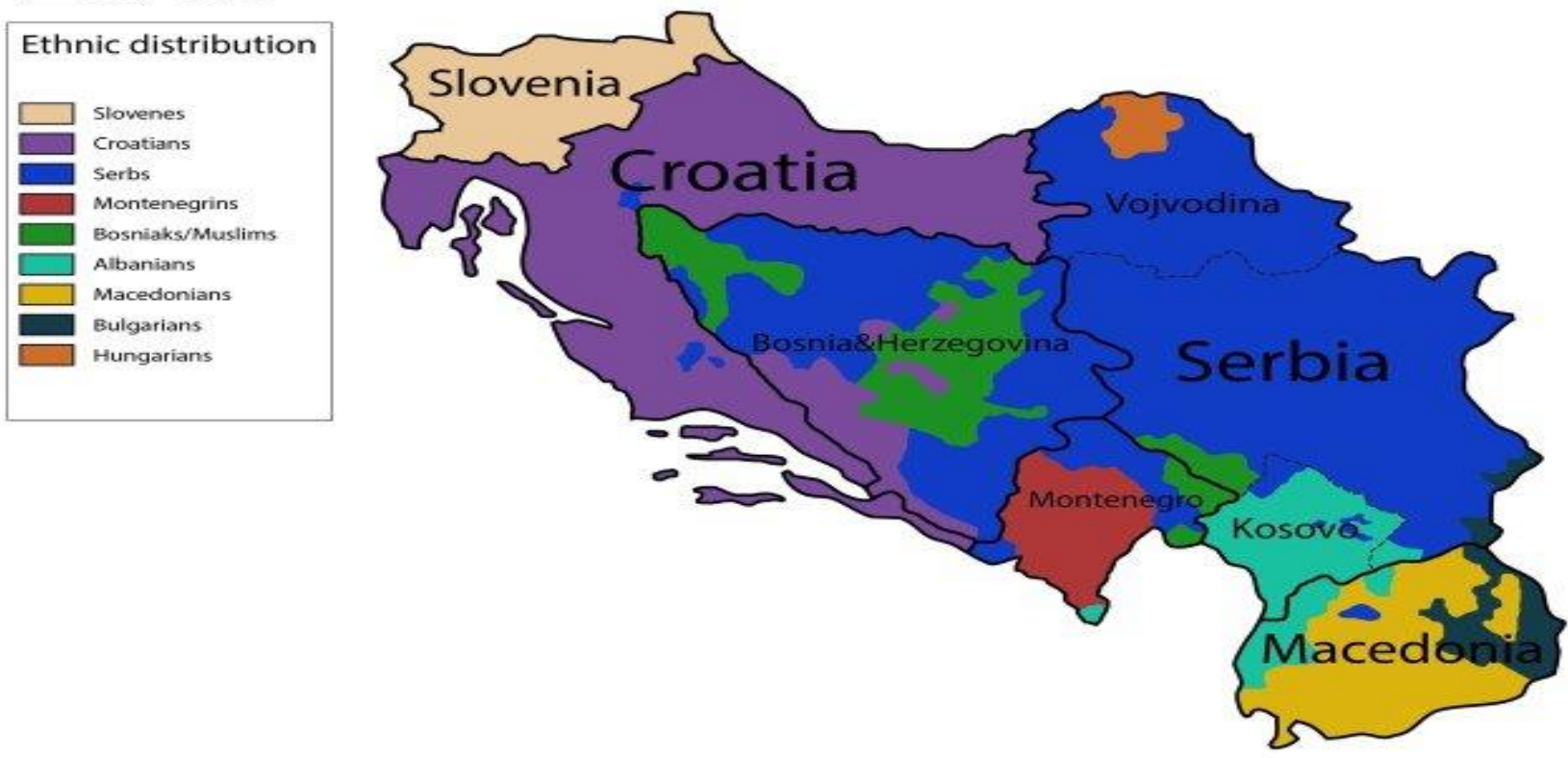

Source: Reddit Inc. (2019). Western Balkans predominant ethnic groups in 1990 and 2015, 2018.

https://www.reddit.com/r/europe/comments/8ycrsa/western balkans_predominant_ethnic gro ups_in_1990/. 


\section{Appendix $\mathbf{D}^{20}$}

Six Indicators of Good Governance and their Components

Voice and Accountability: Democracy Index, Vested interests, Accountability of Public Officials, Human Rights, Freedom of association

Political Stability and Absence of Violence: Orderly transfers, Armed conflict, Violent demonstrations, Social Unrest, International tensions / terrorist threat

Government Effectiveness: Quality of bureaucracy / institutional effectiveness, Excessive bureaucracy / red tape

Regulatory Quality: Unfair competitive practices, Price controls, Discriminatory tariffs, Excessive protections, Discriminatory taxes

Rule of Law: Violent crime, Organized crime, Fairness of judicial process, Enforceability of contracts, Speediness of judicial process, Confiscation/expropriation, Intellectual property rights protection, Private property protection

Control of Corruption: Corruption among public officials

\footnotetext{
${ }^{20}$ Information taken from Economist Intelligence Unit (2015). www.eiu.com.
} 